\title{
Performance of dairy cows fed high levels of acetic acid or ethanol
}

\author{
J. L. P. Daniel,, ${ }^{\star 1}$ R. C. Amaral, ${ }^{*}$ A. Sá Neto, ${ }^{*}$ E. H. Cabezas-Garcia, ${ }^{*}$ A. W. Bispo, ${ }^{*}$ M. Zopollatto, ${ }^{*}$ \\ T. L. Cardoso,† M. H. F. Spoto,† F. A. P. Santos, ${ }^{*}$ and L. G. Nussio* \\ *Department of Animal Science, and \\ †Department of Agri-food Industry, Food and Nutrition, University of São Paulo, "Luiz de Queiroz" College of Agriculture, Piracicaba, SP, Brazil
}

\begin{abstract}
Ethanol and acetic acid are common end products from silages. The main objective of this study was to determine whether high concentrations of ethanol or acetic acid in total mixed ration would affect performance in dairy cows. Thirty mid-lactation Holstein cows were grouped in 10 blocks and fed one of the following diets for $7 \mathrm{wk}$ : (1) control (33\% Bermuda hay $+67 \%$ concentrates), (2) ethanol [control diet $+5 \%$ ethanol, dry matter (DM) basis], or (3) acetic acid (control diet $+5 \%$ acetic acid, DM basis). Ethanol and acetic acid were diluted in water (1:2) and sprayed onto total mixed rations twice daily before feeding. An equal amount of water was mixed with the control ration. To adapt animals to these treatments, cows were fed only half of the treatment dose during the first week of study. Cows fed ethanol yielded more milk $(37.9 \mathrm{~kg} / \mathrm{d})$ than those fed the control $(35.8 \mathrm{~kg} / \mathrm{d})$ or acetic acid $(35.3 \mathrm{~kg} / \mathrm{d})$ diets, mainly due to the higher DM intake (DMI; 23.7, 22.2, and $21.6 \mathrm{~kg} / \mathrm{d}$, respectively). The significant diet $\times$ week interaction for DMI, mainly during wk 2 and 3 (when acetic acid reached the full dose), was related to the decrease in DMI observed for the acetic acid treatment. There was a diet $\times$ week interaction in excretion of milk energy per DMI during wk 2 and 3, due to cows fed acetic acid sustained milk yield despite lower DMI. Energy efficiency was similar across diets. Blood metabolites (glucose, insulin, nonesterified fatty acids, ethanol, and $\gamma$-glutamyl transferase activity) and sensory characteristics of milk were not affected by these treatments. Animal performance suggested similar energy value for the diet containing ethanol compared with other diets. Rumen conversion of ethanol to acetate and a concomitant increase in methane production might be a plausible explanation for the deviation of the predicted energy value based on the heat of combustion. Therefore, the loss of volatile
\end{abstract}

Received February 20, 2012.

Accepted September 24, 2012.

${ }^{1}$ Corresponding author: jldaniel@usp.br compounds during the drying process in the laboratory should be considered when calculating energy content of fermented feedstuffs.

Key words: energy, feed intake, milk quality, volatile organic compound

\section{INTRODUCTION}

Ethanol and acetic acid are volatile organic compounds commonly found in silages (McDonald et al., 1991). In silages inoculated with heterolactic bacteria (e.g., Lactobacillus buchneri), acetic acid is an important fermentation end product with a typical mean concentration of approximately 4\% DM (Kleinschmit and Kung, 2006). Most silages have low concentrations of alcohols (McDonald et al., 1991), but in some cases ethanol can be the main fermentation product instead of lactic acid (Driehuis and van Wikselaar, 2000; Yamamoto et al., 2004). In sugarcane silages, ethanol is the main fermentation product (Kung and Stanley, 1982; Pedroso et al., 2005). Concentrations up to $10 \% \mathrm{DM}$ are common, although levels as high as $22 \%$ DM have been reported in Brazil (Daniel and Nussio, 2011).

Conventionally processed silage samples are virtually free of ethanol and acetic acid due to oven drying before laboratory analysis (Porter and Murray, 2001; Weissbach, 2009). However, fermentation end products are consumed by animals when silages are used as a ration ingredient. The heat of combustion of ethanol (7.1 $\mathrm{Mcal} / \mathrm{kg}$ ) is higher than either acetic acid (3.7 Mcal $/ \mathrm{kg}$ ) or carbohydrates $(4.2 \mathrm{Mcal} / \mathrm{kg})$; therefore, animals fed ethanol could be energetically more efficient. However, most ethanol ingested is partially oxidized to acetate by rumen microorganisms with concomitant increases in methane production (Durix et al., 1991; Yoshii et al., 2005), which might decrease energy efficiency. Indications also exist that milk quality could be negatively affected by the intake of fermentation products in silages (Randby et al. 1999; Randby, 2007). The main objective of this study was to evaluate the effects of diet supplementation with acetic acid and ethanol on performance of mid-lactation dairy cows. 
MATERIALS AND METHODS

\section{Experimental Procedures}

All experimental procedures were approved by the Committee on Animal Use and Care at University of São Paulo/"Luiz de Queiroz" College of Agriculture (Piracicaba, SP, Brazil). Thirty lactating Holstein cows (12 primiparous and 18 multiparous) averaging $245 \pm$ 120 DIM (mean \pm SD) were housed in a tiestall barn. Prior to the treatment period, cows were fed a standard diet (control diet; Table 1) for $14 \mathrm{~d}$ to obtain baseline values for DMI, milk yield, and composition (covariates). At the beginning of the trial, the BW of cows was $638 \pm 60 \mathrm{~kg}$ and milk yield was $39.3 \pm 5.6 \mathrm{~kg} / \mathrm{d}$ (mean $\pm \mathrm{SD})$.

Cows were grouped into 10 blocks based on parity and milk yield and randomly assigned to 1 of 3 dietary treatments over 7 wk: (1) control [33\% Tifton-85 hay (Feno Água Comprida, Guaíra, Brazil) $+67 \%$ concentrates], (2) ethanol [control diet $+5 \%$ ethanol, DM basis (PA; Synth, Diadema, SP, Brazil)], or (3) acetic acid [control diet $+5 \%$ acetic acid, DM basis (PA; Synth)].

Hay bales were chopped three times weekly in a stationary machine (Agroforn, Pardinho, SP, Brazil) and

Table 1. Ingredients and chemical composition of experimental diets (\% of DM)

\begin{tabular}{lccc}
\hline & \multicolumn{3}{c}{ Treatment $^{1}$} \\
\cline { 2 - 4 } Item & Control & Ethanol & Acetic acid \\
\hline Ingredient & & & \\
Bermuda hay & 33.00 & 31.85 & 31.50 \\
Dry ground corn & 29.20 & 28.26 & 27.96 \\
Citrus pulp & 19.10 & 18.59 & 18.38 \\
Soybean meal & 16.40 & 15.78 & 15.70 \\
Mineral-vitamin mix $^{2}$ & 2.30 & 2.32 & 2.20 \\
Ethanol $^{3}$ & - & 3.20 & - \\
Acetic acid & - & - & 4.26 \\
Nutrient & & & \\
DM (\% as fed) & 76.84 & 79.30 & 80.12 \\
OM & 92.51 & 92.66 & 92.82 \\
CP & 17.78 & 17.17 & 17.05 \\
RDP & 11.40 & 10.90 & 11.10 \\
NDF & 37.05 & 35.84 & 35.49 \\
Ether extract $^{4}$ & 2.56 & 2.48 & 2.46 \\
NFC & 35.12 & 37.16 & 37.82 \\
\hline
\end{tabular}

${ }^{1}$ Control $=$ control diet; ethanol $=$ control $\operatorname{diet}+5 \%$ ethanol; acetic acid $=$ control diet $+5 \%$ acetic acid (DM basis).

${ }^{2}$ Mineral-vitamin mix contained (DM basis) $10.0 \%$ Ca, $4.2 \%$ P, $4.5 \%$ $\mathrm{Mg}, 2.0 \% \mathrm{~K}, 1.8 \% \mathrm{~S}, 12.3 \% \mathrm{Na}, 2,800 \mathrm{mg}$ of $\mathrm{Zn} / \mathrm{kg}, 1,400 \mathrm{mg}$ of $\mathrm{Mn} /$ $\mathrm{kg}, 1,050 \mathrm{mg}$ of $\mathrm{Fe} / \mathrm{kg}, 500 \mathrm{mg}$ of $\mathrm{Cu} / \mathrm{kg}, 28 \mathrm{mg}$ of I/ $\mathrm{kg}, 20 \mathrm{mg}$ of $\mathrm{Cr} /$ $\mathrm{kg}, 18 \mathrm{mg}$ of Se/kg, $14 \mathrm{mg}$ of $\mathrm{Co} / \mathrm{kg}, 200,000 \mathrm{IU}$ of vitamin $\mathrm{A} / \mathrm{kg}$, $40,000 \mathrm{IU}$ of vitamin $\mathrm{D}_{3} / \mathrm{kg}, 1,200 \mathrm{IU}$ of vitamin $\mathrm{E} / \mathrm{kg}$, and $80 \mathrm{mg}$ of biotin $/ \mathrm{kg}$.

${ }^{3}$ Puriss grade.

${ }^{4}$ Rumen-degradable protein estimated by NRC (2001).

${ }^{5}$ Including ethanol and acetic acid. stored in a feed box with concentrates. Ration ingredients (Table 1) were mixed for $15 \mathrm{~min}$ in a self-propelled mixer (Data Ranger; American Calan Inc., Northwood, $\mathrm{NH})$ twice daily (0800 and $1800 \mathrm{~h}$ ). Ethanol and acetic acid were diluted in filtered tap water (1:2) and applied onto TMR with a battery-powered sprayer throughout the mixing. An equal amount of water was mixed with the control ration. To adapt the animals to treatments and avoid off feed, cows were fed half of the treatment dose during the first experimental week. The amount of feed offered was adjusted daily to allow more than $10 \%$ orts.

Fractional disappearance rates of dietary ethanol and acetic acid were determined during wk 2 and 6 of the experiment. Approximately $2.5 \mathrm{~kg}$ of TMR was placed in plastic buckets allocated near the feed bunks and samples were collected at $0,0.5,1,2,4,8$, and $12 \mathrm{~h}$ after morning and evening feedings. Fractional disappearance rates were determined by fitting exponential curves to ethanol and acetic acid concentrations over time: $\mathrm{C}_{\mathrm{t}}=\mathrm{C}_{0} \times \mathrm{e}^{-\mathrm{k} \times \mathrm{t}}$, where $\mathrm{C}_{\mathrm{t}}=$ concentration at time t, $\mathrm{C}_{0}=$ initial concentration at time 0 (intercept), $\mathrm{k}=$ disappearance rate constant, and $\mathrm{t}=$ time.

Individual feed intake was determined daily by calculating the difference between the amounts of feed offered and refused. Due to the volatility of the supplemented compounds, 2 variables associated with feed intake were calculated: (1) $\mathbf{D M I}_{\text {oven }}$ was estimated by the DM content of feeds and orts in a forced-air oven (predrying at $55^{\circ} \mathrm{C}$ for $72 \mathrm{~h}$, followed by drying at $105^{\circ} \mathrm{C}$ for $12 \mathrm{~h}$ ); (2) DMI was the sum of $\mathrm{DMI}_{\text {oven }}$ and the estimated ethanol or acetic acid intake, which was corrected for loss during application and TMR exposure at the feed bunk adjusted to eating behavior. For that, feed intake rate $(\mathrm{min} / \mathrm{kg})$ was used to convert the eating time to feed intake for each hour of the day $(\mathrm{kg} / \mathrm{h})$. A constant intake rate was assumed for each animal. From fractional disappearance rates, concentrations of ethanol and acetic acid in TMR were predicted for each hour of a 24 -h period, and the intake of each compound was calculated.

Eating behavior was recorded by visual observation of animals in wk 1, 2, and 6. In wk 1 and 2, eating activity was recorded during a 4-h period following the morning feeding to check if ethanol and acetic acid could impair feed intake via olfaction. In wk 6, eating and ruminating activities were recorded at 10-min intervals throughout a 24 -h period. Chewing (eating + ruminating) per kilogram of DM and NDF were calculated with the DM and NDF intakes during chewing measurement (wk 6).

Cows were injected with recombinant bovine somatotropin (rbST; $500 \mathrm{mg}$ ) every $12 \mathrm{~d}$ and milked twice daily in a milking parlor (0600 and 1700 h). Milk 
production was recorded daily and composite samples were collected in flasks containing bronopol on d 6 and 7 of each experimental week. Milk was analyzed for fat, protein, lactose, casein, FFA, and urea nitrogen by Fourier transform infrared spectroscopy (Lefier et al., 1996), and SCC by flow cytometry (Clínica do Leite, Piracicaba, SP, Brazil). Milk energy content (Mcal/kg) was calculated as milk $\mathrm{NE}_{\mathrm{L}}=0.0929 \times$ fat percentage $+0.0547 \times$ protein percentage $+0.0395 \times$ lactose percentage (NRC, 2001). Daily excretion of milk energy (Mcal/d) was calculated as milk $\mathrm{NE}_{\mathrm{L}} \times$ milk yield.

Unpreserved and unpasteurized milk was collected in wk 6 of the trial and judged immediately after milking for appearance, aroma, taste, and overall quality by a sensory panel of 56 nontrained persons blinded to treatments. Scores were given on a 9-point scale (from $1=$ poor quality to $9=$ high quality) for each attribute (Dutcosky, 2011).

In wk 6, diet digestibility was measured in 15 cows (5 per treatment) by total collection of feces for $3 \mathrm{~d}$. Apparent digestibility of nutrients was calculated as intake of nutrient $(\mathrm{kg} / \mathrm{d})$ minus fecal excretion of nutrient $(\mathrm{kg} / \mathrm{d})$ divided by intake. Total digestible nutrients were estimated through nutrient digestibilities (NRC, 2001). Ethanol and acetic acid were considered as containing $100 \%$ TDN. Cows were weighed and scored for body condition after milking in the afternoon (BCS from 1 to 5; Wildman et al., 1982) at the beginning and end of the trial. Energy partitioning (maintenance, reserves, and lactation) was calculated with equations from NRC (2001) using data from individual cows.

Blood samples were obtained from coccygeal vessels $1 \mathrm{~h}$ before and $6 \mathrm{~h}$ after morning feeding on wk 1,2 and 6 . Samples were collected in 7 -mL vacuum tubes containing sodium heparin. Plasma was separated by centrifugation $(2,000 \times g$ for $20 \mathrm{~min})$ and submitted to a commercial laboratory (Plimorlabor, Piracicaba, Brazil) for glucose (glucose oxidase; Trinder, 1969), insulin (chemiluminescence immunoassay; Vlasenko et al., 1989), NEFA (spectrophotometry; Johnson and Peters, 1993), ethanol (gas chromatography; Tietz, 1976), and $\gamma$-glutamyl transferase activity (enzymatic method; Szasz, 1969) analysis.

Samples of feeds, TMR, and orts were collected weekly, composited by cow and oven dried $(72 \mathrm{~h}$ at $60^{\circ} \mathrm{C}$ ), as were feces collected during the digestion trial. Water extracts (Kung et al., 1984) were also prepared from TMR samples. Acetic acid content was analyzed by gas chromatography (Palmquist and Conrad, 1971) and ethanol content was determined using a procedure for markedly turbid samples (Sigma procedure no. 332UV; Kung et al., 2000). Dried samples were ground through a 1-mm screen (Wiley mill). Subsamples were analyzed for $\mathrm{DM}$ in an air-forced oven at $105^{\circ} \mathrm{C}$ (AOAC,
1980), CP by the Dumas method (Wiles et al., 1998), ether extract (AOAC, 1990), ash (AOAC, 1980), NDF (assayed with sodium sulfite and amylase; ash free), ADF (nonsequential), sulfuric acid lignin (Van Soest et al., 1991), neutral detergent insoluble CP (NDICP), and acid detergent insoluble CP (Goering and Van Soest, 1970). For ethanol and acetic acid diets, nutrient concentrations were corrected by including ethanol and acetic acid as part of the total DM. Thus, NFC were calculated as $100-[\mathrm{CP}+(\mathrm{NDF}-\mathrm{NDICP})+\mathrm{EE}+$ ash], where $\mathrm{EE}=$ ether extract.

\section{Statistical Analysis}

Statistical analysis was performed by the repeated measures approach of the PROC MIXED of SAS (Littell et al., 1998; SAS Institute, 2001). The covariance structure used was the one with the smaller value for the Akaike information criterion. Covariance structures considered were autoregressive(1), compound symmetry, unstructured, and variance components. The following model was used: $\mathrm{y}_{\mathrm{ijk}}=\mu+\mathrm{COV}+\alpha_{\mathrm{i}}+\beta_{\mathrm{j}}+$ $\alpha \beta_{\mathrm{ij}}+\gamma_{\mathrm{k}}+\beta \gamma_{\mathrm{jk}}+\varepsilon_{\mathrm{ijk}}$, where $y_{\mathrm{ijk}}=$ dependent variable, $\mu=$ overall mean, $\mathrm{COV}=$ covariate (measurement of the same variable made during the pretreatment period), $\alpha_{\mathrm{i}}=$ random effect of block ( $\mathrm{i}=1$ to 10$), \beta_{\mathrm{j}}=$ fixed effect of treatment $(j=$ control, ethanol, or acetic acid), $\alpha \beta_{\mathrm{ij}}=$ error term to test whole-plot effects, $\gamma_{\mathrm{k}}=$ fixed effect of week ( $\mathrm{k}=1$ to 7$), \beta \gamma_{\mathrm{jk}}=$ interaction of treatment and week, and $\varepsilon_{\mathrm{ijk}}=$ residual error. Single measurements were analyzed with block and treatment effects in the model. Means were compared using the Tukey-Kramer test at 5 and 10\% significance levels. Because the original data from the milk sensory panel did not fit a normal distribution, a Box-Cox transformation was performed by the PROC TRANSREG of SAS.

\section{RESULTS AND DISCUSSION}

The use of hay as the only forage source allowed for the addition of ethanol and acetic acid without any contamination of fermentation end products, which are normally found in fermented feedstuffs. However, some of the added compounds were lost by volatilization during diet mixing and feeding. Therefore, actual doses at the feed bunk were $3.20 \%$ ethanol and $4.26 \%$ acetic acid (Table 1). Higher losses of ethanol compared with acetic acid occurred due to the higher vapor pressure of ethanol (Atkins, 1994).

In addition, more ethanol and acetic acid were lost due to exposure at the feed bunk (Figure 1), either by volatilization (Mitloehner et al., 2009) or aerobic microbial oxidation (Spoelstra et al., 1988), although this partitioning was not assessed in the present trial. 


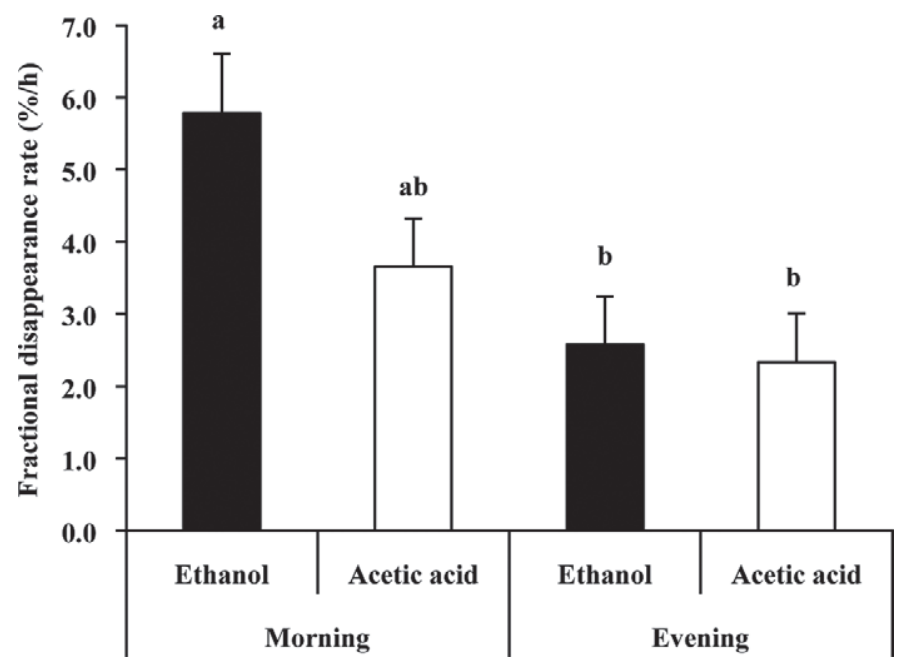

Figure 1. Fractional disappearance rates of ethanol and acetic acid from TMR at the feed bunk, according to feeding time (morning or evening). $P=0.14$ for compound effect, $P=0.02$ for feeding time effect, and $P=0.22$ for compound $\times$ feeding time interaction. Means with different letters $(\mathrm{a}$ and $\mathrm{b})$ differ $(P<0.10)$. Bars denote SEM.

Fractional disappearance rates of ethanol and acetic acid were associated with feeding time. The TMR delivered in the morning had a higher rate of ethanol loss and tended to have a greater loss of acetic acid than in the evening, possibly due to higher temperature $\left(29.9^{\circ} \mathrm{C}\right.$ during the day and $22.4^{\circ} \mathrm{C}$ during the night) at the tiestall barn. Considering fractional disappearance rates and eating behavior, it was estimated that $92 \%$ of

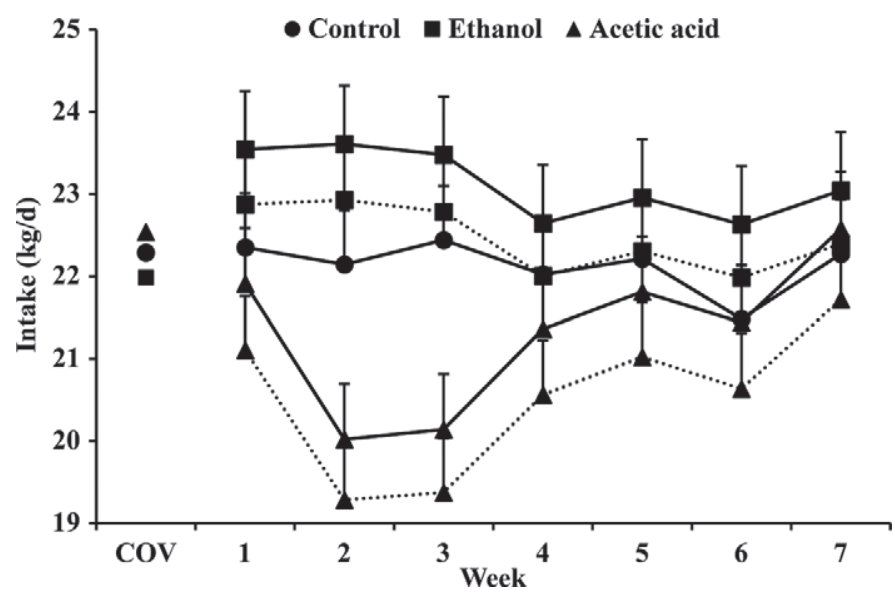

Figure 2. Voluntary feed intake during the trial. Solid line $=$ DMI considering the consumption of ethanol and acetic acid $(P=0.07$ for diet effect, $P<0.01$ for week effect, and $P=0.02$ for diet $\times$ week interaction). Dotted line $=\mathrm{DMI}_{\text {oven }}$ (estimated by the DM content of feeds and orts in a forced-air oven) without considering the consumption of ethanol and acetic acid $(P=0.02$ for diet effect, $P<0.01$ for week effect, and $P=0.02$ for diet $\times$ week interaction). COV $=$ covariate. Bars denote SEM. the ethanol and $90 \%$ of the acetic acid available at the feed bunk were actually consumed by cows.

The method adopted to calculate feed intake affected results and their interpretations. If DM of a TMR containing volatile compounds (e.g., ethanol and acetic acid) is measured in the oven, most of these compounds will evaporate and actual DMI will be underestimated. In the current study, $\mathrm{DMI}_{\text {oven }}$ was not affected by ethanol addition but was depressed by acetic acid. Others found that ethanol did not impair voluntary feed intake (Ham et al., 1994; Randby et al., 1999). When the mass of ethanol was considered, DMI was higher for the ethanol-containing diet (Figure 2).

Regardless of the calculation method, acetic acid depressed DMI for 2 wk following the full dose application (wk 2 and 3 ), but its deleterious effect disappeared after wk 4. Krizsan et al. (2006) fed acetic acid to steers and also observed lower $\mathrm{DMI}_{\text {oven }}$; nevertheless, they reported similar DMI across all experimental treatments when the mass of supplement was taken into account, which is in agreement with the findings of Hutchinson and Wilkins (1971).

Eating, ruminating, and chewing time $(\mathrm{min} / \mathrm{d})$ and chewing per kilogram of DM or NDF intake were unchanged across treatments, during the 1-d observation. Eating time during the 4 -h period following the morning feeding was lower for the acetic acid treatment; however, differences across treatments were not observed for the whole day (Table 2). The tendency for a higher disappearance rate of acetic acid after the morning feeding may have led to feed refusal due to olfaction (Forbes, 2007). Hutchinson and Wilkins (1971) observed similar changes in the eating pattern of sheep fed ryegrass silage supplemented with acetic acid $(2,5$, and $8.8 \% \mathrm{DM})$. Moreover, eating time decreased dur-

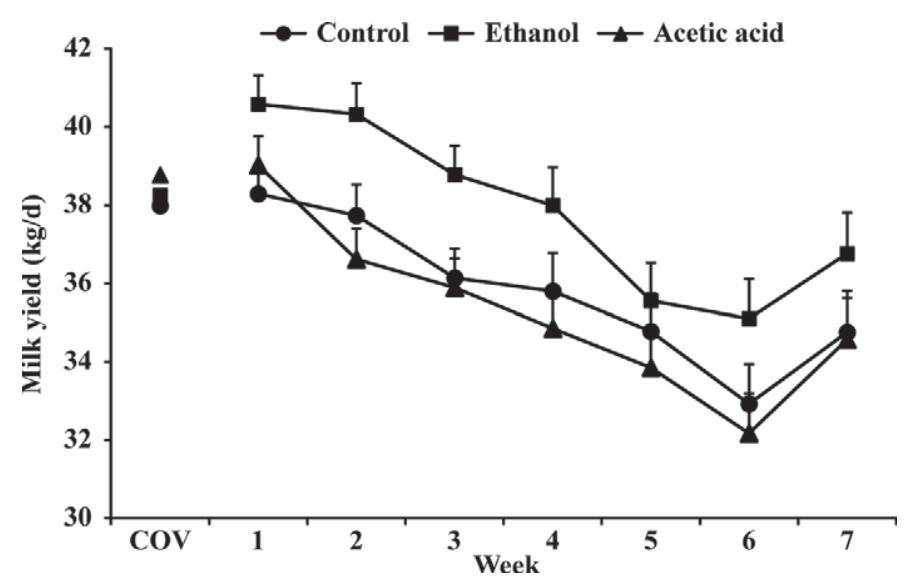

Figure 3. Milk yield of cows fed ethanol or acetic acid. $P=0.04$ for diet effect, $P<0.01$ for week effect, and $P=0.13$ for $\operatorname{diet} \times$ week interaction. $\mathrm{COV}=$ covariate. Bars denote SEM. 
Table 2. Ingestive behavior of cows fed control, ethanol, and acetic acid diets

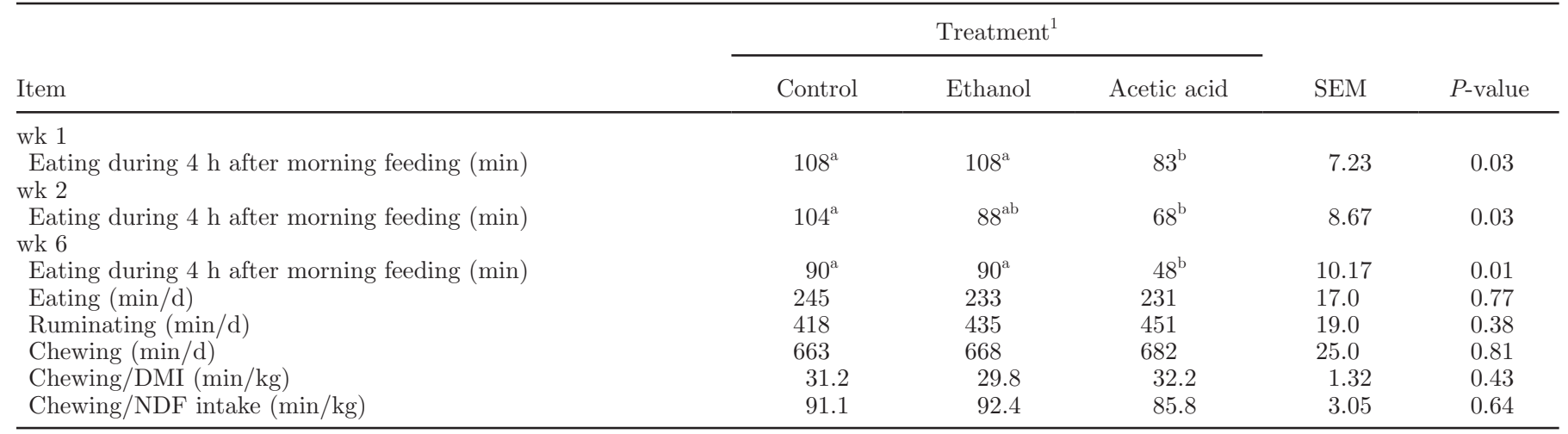

$\overline{\mathrm{a}, \mathrm{b}}$ Means within a row with different superscripts differ $(P<0.10)$.

${ }^{1}$ Control $=$ control diet; ethanol $=$ control diet $+5 \%$ ethanol; acetic acid $=$ control diet $+5 \%$ acetic acid $(\mathrm{DM}$ basis $)$.

ing a 4-h period following the diet offering, but the opposite occurred between 16 to $20 \mathrm{~h}$ after feeding (Hutchinson and Wilkins, 1971). Because acetate is produced in large amounts in the rumen, it seems unlikely that DMI was metabolically controlled by dietary acetate. Assuming a ruminal acetate yield of $3 \mathrm{~mol} / \mathrm{kg}$ of DMI (Bergman, 1990; Resende Júnior et al., 2006), supplemental acetic acid could represent less than $18 \%$ of total acetate absorbed daily by our cows.

Milk yield was greater for cows fed ethanol. Although DMI was depressed for cows fed acetic acid during the first several weeks, average milk production throughout the study was not different from the control (Figure 3). The content of all milk components was unaffected by the treatments (Table 3 ), but a diet $\times$ week interaction $(P=0.03)$ existed for milk fat due to the higher milk fat content in acetic acid treatment during wk 2 and 3.
On the other hand, ethanol did not increase milk fat content as expected based on published data (Orskov et al., 1967; Pradhan and Hemken, 1970; Randby et al., 1999). Cows fed an ethanol diet yielded more lactose and tended $(P=0.06)$ to yield more milk protein. Ethanol supply may have changed the overall energy status of cows and spared glucose and glucogenic amino acids (Danfaer, 1994; Hanigan et al., 1998; Randby et al., 1999).

At the sensory panel, all diets led to well-accepted milk batches (scores >6.6). The appearance, aroma, and taste of milk were not affected by treatments (Table 4). However, the overall milk quality was higher for cows fed ethanol and acetic acid compared with cows fed the control diet. Unlike the results of Randby et al. (1999), who reported that ethanol reduced the organoleptic quality of milk, our results showed that

Table 3. Dry matter intake, milk yield, and milk composition of cows fed control, ethanol, and acetic acid diets

\begin{tabular}{|c|c|c|c|c|c|c|c|}
\hline Item & \multicolumn{3}{|c|}{ Treatment $^{1}$} & SEM & \multicolumn{3}{|c|}{$P$-value } \\
\hline DMI $(\mathrm{g} / \mathrm{d})$ & $22.1^{\mathrm{ab}}$ & $23.1^{\mathrm{a}}$ & $21.3^{\mathrm{b}}$ & 0.54 & 0.07 & $<0.01$ & 0.02 \\
\hline Fat $(\%)$ & 3.55 & 3.43 & 3.69 & 0.11 & 0.20 & $<0.01$ & 0.03 \\
\hline Fat $(\mathrm{kg})$ & 1.25 & 1.29 & 1.31 & 0.05 & 0.74 & $<0.01$ & 0.10 \\
\hline Protein (\%) & 3.32 & 3.33 & 3.29 & 0.03 & 0.56 & $<0.01$ & 0.29 \\
\hline Casein/protein (\%) & 77.0 & 76.6 & 76.8 & 0.20 & 0.43 & $<0.01$ & 0.36 \\
\hline Lactose $(\%)$ & 4.67 & 4.65 & 4.67 & 0.03 & 0.84 & $<0.01$ & 0.83 \\
\hline Lactose (kg) & $1.65^{\mathrm{d}}$ & $1.76^{\mathrm{c}}$ & $1.64^{\mathrm{d}}$ & 0.04 & 0.03 & $<0.01$ & 0.79 \\
\hline $\mathrm{FFA}(\mu \mathrm{mol} / \mathrm{dL})$ & 3.23 & 4.26 & 6.37 & 1.08 & 0.12 & $<0.01$ & 0.35 \\
\hline Urea N (mg/dL) & 13.2 & 12.5 & 12.5 & 0.39 & 0.30 & $<0.01$ & 0.20 \\
\hline $\mathrm{SCC}(\times 1.000 / \mathrm{mL})$ & 105 & 120 & 107 & - & - & - & - \\
\hline
\end{tabular}

${ }^{\mathrm{a}, \mathrm{b}}$ Means within a row with different superscripts differ $(P<0.10)$.

${ }^{\mathrm{c}, \mathrm{d}}$ Means within a row with different superscripts differ $(P<0.05)$.

${ }^{1}$ Control $=$ control diet; ethanol $=$ control diet $+5 \%$ ethanol; acetic acid $=$ control diet $+5 \%$ acetic acid $(\mathrm{DM}$ basis $)$. 
Table 4. Sensory milk quality of cows fed control, ethanol, and acetic acid diets

\begin{tabular}{|c|c|c|c|c|c|}
\hline \multirow[b]{2}{*}{ Item } & \multicolumn{3}{|c|}{ Treatment $^{1}$} & \multirow[b]{2}{*}{ SEM } & \multirow[b]{2}{*}{$P$-value } \\
\hline & Control & Ethanol & Acetic acid & & \\
\hline Appearance & 7.35 & 7.45 & 7.50 & - & - \\
\hline Appearance transformed ${ }^{2}$ & 27.9 & 28.6 & 28.8 & 1.28 & 0.88 \\
\hline Aroma & 6.65 & 7.78 & 6.86 & - & - \\
\hline Aroma transformed ${ }^{2}$ & 21.9 & 24.8 & 25.5 & 1.38 & 0.15 \\
\hline Taste & 7.13 & 7.36 & 7.43 & - & - \\
\hline Taste transformed ${ }^{2}$ & 26.2 & 27.9 & 28.4 & 1.23 & 0.40 \\
\hline Overall quality $^{3}$ & 7.28 & 7.48 & 7.56 & - & - \\
\hline Overall quality transformed $^{2}$ & $25.8^{\mathrm{b}}$ & $28.9^{\mathrm{a}}$ & $30.1^{\mathrm{a}}$ & 1.13 & 0.02 \\
\hline
\end{tabular}

${ }_{\mathrm{a}, \mathrm{b}}$ Means within a row with different superscripts differ $(P<0.05)$.

${ }^{1}$ Control $=$ control diet; ethanol $=$ control diet $+5 \%$ ethanol; acetic acid $=$ control diet $+5 \%$ acetic acid $(\mathrm{DM}$ basis).

${ }^{2}$ Box-Cox transformation.

${ }^{3}$ Overall quality was judged by panelists. It combines all organoleptic attributes of milk samples.

Table 5. Apparent digestibility of nutrients in control, ethanol, and acetic acid diets $(\mathrm{n}=15)$

\begin{tabular}{lccccc}
\hline & \multicolumn{4}{c}{ Treatment $^{1}$} \\
\cline { 2 - 4 } Item & Control & Ethanol & Acetic acid & SEM & $P$-value \\
\hline DM (\%) & 71.38 & 69.23 & 70.21 & 1.86 & 0.74 \\
OM (\%) & 74.94 & 76.27 & 76.22 & 1.20 & 0.60 \\
CP (\%) & 71.09 & 72.20 & 70.30 & 1.85 & 0.66 \\
NDF (\%) & 65.76 & 65.95 & 66.13 & 2.37 & 0.99 \\
Diet TDN (\%) & 72.09 & 72.94 & 73.49 & 1.18 & 0.70 \\
\hline
\end{tabular}

${ }^{1}$ Control $=$ control diet; ethanol $=$ control diet $+5 \%$ ethanol; acetic acid $=$ control diet $+5 \%$ acetic acid $(\mathrm{DM}$ basis).

Table 6. Body weight, BCS change, and energy partitioning of cows fed control, ethanol, and acetic acid diets

\begin{tabular}{|c|c|c|c|c|c|}
\hline \multirow[b]{2}{*}{ Item } & \multicolumn{3}{|c|}{ Treatment $^{1}$} & \multirow[b]{2}{*}{ SEM } & \multirow[b]{2}{*}{$P$-value } \\
\hline & Control & Ethanol & Acetic acid & & \\
\hline BW (kg) & 641 & 621 & 652 & 19.1 & 0.46 \\
\hline BW change $(\mathrm{kg} / \mathrm{d})$ & 0.11 & 0.08 & -0.00 & 0.13 & 0.82 \\
\hline BCS change (/7 wk) & 0.13 & 0.08 & 0.03 & 0.07 & 0.63 \\
\hline $\mathrm{NE}_{\mathrm{M}}^{2}(\mathrm{Mcal} / \mathrm{d})$ & 10.2 & 9.97 & 10.3 & 0.21 & 0.44 \\
\hline $\mathrm{NE}_{\mathrm{L}}$ required for $\mathrm{BW}$ change $^{2}(\mathrm{Mcal} / \mathrm{d})$ & 0.91 & 0.57 & 0.16 & 0.54 & 0.63 \\
\hline $\mathrm{NE}_{\mathrm{L}}$ lactation $^{2}(\mathrm{Mcal} / \mathrm{d})$ & 24.7 & 25.5 & 25.2 & 0.94 & 0.75 \\
\hline Total $\mathrm{NE}_{\mathrm{L}}(\mathrm{Mcal} / \mathrm{d})$ & 35.8 & 36.1 & 35.8 & 1.02 & 0.96 \\
\hline $\mathrm{NE}_{\mathrm{L}}$ lactation/DMI (Mcal/kg) & $1.12^{\mathrm{b}}$ & $1.12^{\mathrm{b}}$ & $1.19^{\mathrm{a}}$ & 0.02 & $<0.01$ \\
\hline Total $\mathrm{NE}_{\mathrm{L}} / \mathrm{DMI}(\mathrm{Mcal} / \mathrm{kg})$ & 1.62 & 1.59 & 1.67 & 0.04 & 0.24 \\
\hline
\end{tabular}

$\overline{\mathrm{a}, \mathrm{b}}$ Means within a row with different superscripts differ $(P<0.05)$.

${ }^{1}$ Control $=$ control diet; ethanol $=$ control diet $+5 \%$ ethanol; acetic acid $=$ control diet $+5 \%$ acetic acid $(\mathrm{DM}$ basis).

${ }^{2}$ Estimated by equations from NRC (2001).

consumption of ethanol by cows improved milk sensory quality. Differences in experimental length may affect the capacity of rumen microbes and tissues to metabolize ethanol (Orskov et al., 1967; Jean-Blain et al., 1992; Raun and Kristensen, 2011) and may explain different findings among experiments. The higher proportion of concentrates may have contributed to the good milk sensory quality found in the present study (Pradhan and Hemken, 1970; Adler and Randby, 2007). Moreover, off-flavors in milk may be due more to differences in a group of common compounds rather than from the absence or presence of a single compound (Mounchili et al., 2005).

Apparent digestibility of nutrients (Table 5), BW, and BCS changes (Table 6) were not altered across treatments. Energy efficiency of the ethanol-containing 


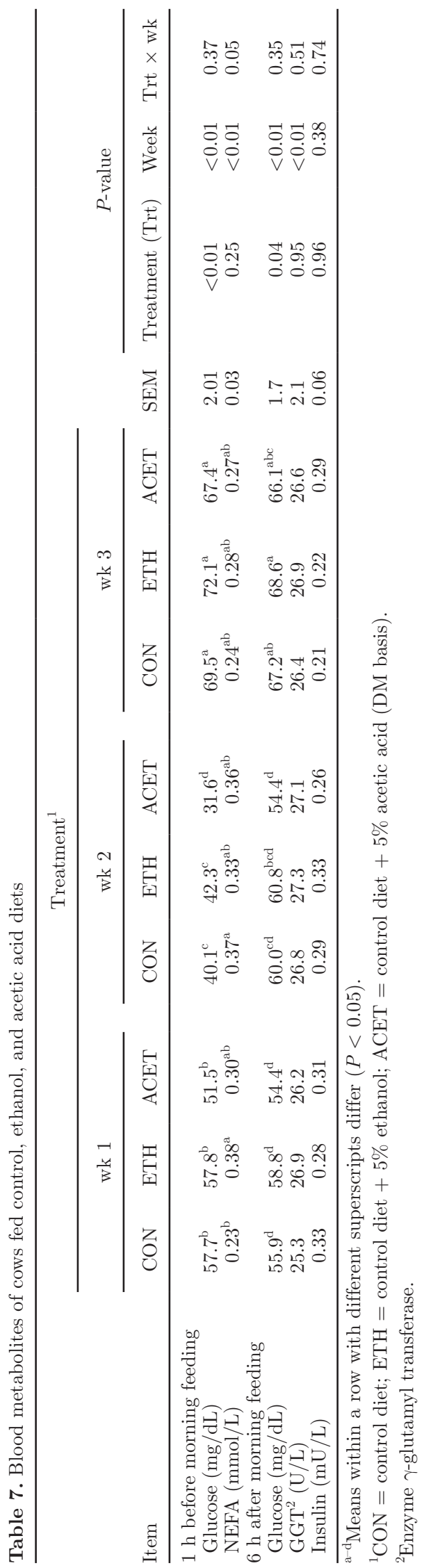

diet was similar to other diets (average $1.63 \mathrm{Mcal} /$ $\mathrm{kg})$. Ham et al. (1994) and Randby et al. (1999) also found similar values for energy efficiency in diets with or without ethanol. Although it was not measured in this study, the oxidation of ethanol to acetate by rumen microorganisms is a plausible explanation for the deviation of the predicted energy value based on the heat of combustion (Durix et al., 1991; Jean-Blain et al., 1992; Yoshii et al., 2005; Raun and Kristensen, 2011). Conversely, cows fed acetic acid had higher milk $\mathrm{NE}_{\mathrm{L}} / \mathrm{DMI}$ than those fed control and ethanol diets, due to the sustained milk yield despite lower DMI $(P=$ 0.06 for diet $\times$ week interaction). However, after cows fed acetic acid recovered DMI (from wk 4 forward), milk energy excretion per kilogram of DMI was similar across treatments $(1.1 \mathrm{Mcal} / \mathrm{kg})$. By replacing DMI with $\mathrm{DMI}_{\text {oven }}$ at calculation, energy efficiency of diets containing ethanol or acetic acid were overestimated $(1.64$ vs. $1.59 \mathrm{Mcal} / \mathrm{kg}$ for ethanol and 1.74 vs. 1.67 $\mathrm{Mcal} / \mathrm{kg}$ for acetic acid), which indicates the significant contribution of these chemical compounds to animal performance. When losses of volatile compounds during the drying process of fermented feedstuffs (e.g., silages) in the laboratory occurs, including their estimated loss in the NFC fraction (NRC, 2001) is a suitable alternative to computing their energy value without biases.

Most blood metabolites were unaffected by treatments (Table 7). The concentration of NEFA was lower in the control diet during the first week of comparison, but this effect disappeared in later sampling. Cows fed acetic acid had lower plasma glucose concentrations either before or $6 \mathrm{~h}$ after feeding, which was associated with lower DMI. Unexpectedly, the ethanol-containing diet did not affect blood metabolites. Even the activity of the enzyme $\gamma$-glutamyl transferase in blood, which is typically associated with ethanol consumption, remained within the normal range in cattle (Tennant and Center, 2008). The plasmatic concentration of ethanol was below the detection limit $(0.01 \mathrm{~g} / \mathrm{L})$ in all cows. Raun and Kristensen (2011) also did not detect ethanol in arterial blood sampled immediately before or $6 \mathrm{~h}$ after feeding. The conversion of ethanol to acetate in the rumen (Durix et al., 1991; Jean-Blain et al., 1992; Yoshii et al., 2005) may be a plausible explanation for the absence of blood metabolite alterations.

\section{CONCLUSIONS}

Ethanol and acetic acid contributed significantly to animal performance, although the ethanol-containing diet had energy efficiency similar to the other diets. When losses of volatile compounds during the drying process of fermented feedstuffs in the laboratory occurs, including their estimated loss in the NFC fraction 
(NRC, 2001) is a suitable alternative to computing their energy value without biases. The intake of ethanol and acetic acid did not negatively affect the composition and sensory quality of milk.

\section{ACKNOWLEDGMENTS}

The authors are grateful to the financial support of Fundação de Amparo à Pesquisa do Estado de São Paulo (FAPESP, São Paulo, SP, Brazil), Conselho Nacional de Desenvolvimento Científico e Tecnológico (CNPq, Brasília, Brazil), and Coordenação de Aperfeiçoamento de Pessoal de Nível Superior (CAPES, Brasília, Brazil) foundations.

\section{REFERENCES}

Adler, S. A., and A. T. Randby. 2007. The effect of preservation method of barley, maturity of grass silage, and type of protein supplement on sensory milk quality in organic farming. J. Anim. Feed Sci. 16(Suppl. 1):75-78.

AOAC (Association of Official Analytical Chemists). 1980. Official Methods of Analysis. 13th ed. AOAC, Washington, DC.

AOAC (Association of Official Analytical Chemists). 1990. Official Methods of Analysis. 15th ed. AOAC, Arlington, VA.

Atkins, P. W. 1994. Physical Chemistry. 5th ed. Oxford University Press, Oxford, UK.

Bergman, E. N. 1990. Energy contributions of volatile fatty acids from the gastrointestinal tract in various species. Physiol. Rev. 70:567-590.

Danfaer, A. 1994. Nutrient metabolism and utilization in the liver. Livest. Prod. Sci. 39:115-127.

Daniel, J. L. P., and L. G. Nussio. 2011. Contribution of silage volatile compounds for the animal nutrition. Pages 279-306 in Proc. 2th Intl. Symp. Forage Qual. Conserv., São Pedro, Brazil. FEALQ, Piracicaba, Brazil

Driehuis, F., and P. G. van Wikselaar. 2000. The occurrence and prevention of ethanol fermentation in high-dry-matter grass silage. J. Sci. Food Agric. 80:711-718.

Durix, A., C. Jean-Blain, H. P. Sallmann, and J. P. Jouany. 1991. Use of a semicontinuous culture system (RUSITEC) to study the metabolism of ethanol in the rumen and its effects on ruminal digestion. Can. J. Anim. Sci. 71:115-123.

Dutcosky, S. D. 2011. Análise sensorial de alimentos. 3rd ed. Champagnat, Curitiba, Brazil.

Forbes, J. M. 2007. Voluntary food intake and diet selection in farm animals. 2nd ed. CABI, Wallingford, UK.

Goering, H. K., and P. J. Van Soest. 1970. Forage Fiber Analyses (Apparatus, Reagents, Procedures, and Some Applications). Agric. Handbook No. 379. Agricultural Research Service-US Department of Agriculture (ARS-USDA), Washington, DC.

Ham, G. A., R. A. Stock, T. J. Klopfenstein, E. M. Larson, D. H. Shain, and R. P. Huffman. 1994. Wet corn distillers byproducts compared with dried corn distillers grain with soluble as a source of protein and energy for ruminants. J. Anim. Sci. 72:3246-3257.

Hanigan, M. D., J. P. Cant, D. C. Weakley, and J. L. Beckett. 1998. An evaluation of postabsorptive protein and amino acid metabolism in the lactating dairy cow. J. Dairy Sci. 81:3385-3401.

Hutchinson, K. J., and R. J. Wilkins. 1971. The voluntary intake of silage by sheep. II. The effects of acetate on silage intake. J. Agric. Sci. 77:539-543.

Jean-Blain, C., A. Durix, and B. Tranchant. 1992. Kinetics of ethanol metabolism in sheep. Reprod. Nutr. Dev. 32:83-90.

Johnson, M. M., and J. P. Peters. 1993. Technical note: An improved method to quantify nonesterified fatty acids in bovine plasma. J. Anim. Sci. 71:753-756.
Kleinschmit, D. H., and L. Kung Jr. 2006. A meta-analysis of the effects of Lactobacillus buchneri on the fermentation and aerobic stability of corn and grass and small-grain silages. J. Dairy Sci. 89:4005-4013.

Krizsan, S. J., A. T. Randby, and F. Westad. 2006. The effect of acetic acid, caproic acid and tryptamine on voluntary intake of grass silage by growing cattle. Pages $143-145$ in Proc. 12th Intl. Symp. Forage Conserv., Brno, Czech Republic. VFU, Brno, Czech Republic.

Kung, L., Jr., D. B. Grieve, J. W. Thomas, and J. T. Huber. 1984. Added ammonia or microbial inocula for fermentation and nitrogenous compounds of alfalfa ensiled at various percents of dry matter. J. Dairy Sci. 67:299-306.

Kung, L., Jr., J. R. Robinson, N. K. Ranjit, J. H. Chen, C. M. Golt, and J. D. Pesek. 2000. Microbial populations, fermentation endproducts, and aerobic stability of corn silage treated with ammonia or a propionic acid-based preservative. J. Dairy Sci. 83:14791486.

Kung, L., Jr., and R. W. Stanley. 1982. Effect of stage of maturity on the nutritive value of whole-plant sugarcane preserved as silage. J. Anim. Sci. 54:689-696.

Lefier, D., R. Grappin, and S. Pochet. 1996. Determination of fat, protein, and lactose in raw milk by Fourier transform infrared spectroscopy and by analysis with a conventional filter-based milk analyzer. J. AOAC Int. 79:711-717.

Littell, R. C., P. R. Henry, and C. B. Ammerman. 1998. Statistical analysis of repeated measures data using SAS procedures. J. Anim. Sci. 76:1216-1231.

McDonald, P., N. Henderson, and S. Heron. 1991. The Biochemistry of Silage. 2nd ed. Chalcombe Publications, Marlow, UK.

Mitloehner, F. M., I. L. Malkina, A. Kumar, and P. G. Green. 2009. Volatile organic compounds emitted from dairy silages and other feeds. Pages 15-26 in Proc. 15th Intl. Silage Conf., Madison, WI. US Dairy Forage Research Center, Madison, WI.

Mounchili, A., J. J. Wichtel, J. O. Bosset, I. R. Dohoo, M. Imhof, D. Altieri, S. Mallia, and H. Stryhn. 2005. HS-SPME gas chromatographic characterization of volatile compounds in milk tainted with off-flavour. Int. Dairy J. 15:1203-1215.

NRC. 2001. Nutrient Requirements of Dairy Cattle. 7th rev. ed. National Academy Press, Washington, DC.

Orskov, E. R., R. W. Hemken, and L. A. Moore. 1967. Effect of ethanol infusion on milk fat content and composition and on volatile fatty acids in the rumen liquor. J. Dairy Sci. 50:692-695.

Palmquist, D. L., and H. R. Conrad. 1971. Origin of plasma fatty acids in lactating cows fed high grain or high fat diets. J. Dairy Sci. 54:1025-1033.

Pedroso, A. F., L. G. Nussio, S. de Fátima Paziani, D. R. S. Loures, M. S. Igarasi, R. M. Coelho, I. H. Packer, J. Horii, and L. H. Gomes. 2005. Fermentation and epiphytic microflora dynamics in sugarcane silage. Scientia Agricola 62:427-432.

Porter, M. G., and R. S. Murray. 2001. The volatility of components of grass silage on oven drying and the inter-relationship between drymatter content estimated by different analytical methods. Grass Forage Sci. 56:405-411.

Pradhan, K., and R. W. Hemken. 1970. Utilization of ethanol and its effect on fatty acid patterns in ruminants. J. Dairy Sci. 53:17391746 .

Randby, A. T. 2007. Effect of propanol and dimethylsulphide in grass silage on organoleptic milk quality. J. Anim. Feed Sci. 16(Suppl. 1):102-107.

Randby, A. T., I. Selmer-Olsen, and L. Baevre. 1999. Effect of ethanol in feed on milk flavor and chemical composition. J. Dairy Sci. 82:420-428.

Raun, B. M. L., and N. B. Kristensen. 2011. Metabolic effects of feeding ethanol or propanol to postpartum transition Holstein cows. J. Dairy Sci. 94:2566-2580.

Resende Júnior, J. C., M. N. Pereira, H. Boer, and S. Tamminga. 2006. Comparison of techniques to determine the clearance of ruminal volatile fatty acids. J. Dairy Sci. 89:3096-3106.

SAS Institute. 2001. SAS/STAT User's Guide. Version 8.2. 5th ed. SAS Institute Inc., Cary, NC. 
Spoelstra, S. F., M. G. Courtin, and J. A. C. van Beers. 1988. Acetic acid bacteria can initiate aerobic deterioration of whole crop maize silage. J. Agric. Sci. 111:127-132.

Szasz, G. 1969. A kinetic photometric method for serum $\gamma$-glutamyl transpeptidase. Clin. Chem. 15:124-136.

Tennant, B. C., and S. A. Center. 2008. Hepatic function. Pages 379 412 in Clinical biochemistry of Domestic Animals. 6th ed. J. J. Kaneko, J. W. Harvey, and M. L. Bruss, ed. Elsevier, San Diego, CA.

Tietz, N. W. 1976. Determination of alcohols by gas chromatography. Pages 1110-1111 in Fundamentals of Clinical Chemistry. Saunders Co., Philadelphia, PA.

Trinder, P. 1969. Determination of glucose in blood using glucose oxidase with an alternative oxygen receptor. Ann. Clin. Biochem. 6:24-27.

Van Soest, P. J., J. B. Robertson, and B. A. Lewis. 1991. Methods for dietary fiber, neutral detergent fiber, and nonstarch polysaccharides in relation to animal nutrition. J. Dairy Sci. 74:3583-3597.

Vlasenko, S. B., A. A. Arefyev, A. D. Klimov, B. B. Kim, E. L. Gorovits, A. P. Osipov, E. M. Gavrilova, and A. M. Yegorov. 1989. An investigation on the catalytic mechanism of enhanced chemilumi- nescence: Immunochemical applications of this reaction. J. Biolumin. Chemilumin. 4:164-176.

Weissbach, F. 2009. Correction of dry matter content of silages used as substrate for biogas production. Pages 483-484 in Proc. 15th Intl. Silage Conf., Madison, WI. US Dairy Forage Research Center, Madison, WI.

Wildman, E. E., G. M. Jones, P. E. Wagner, R. L. Boman, H. F. Troutt Jr., and T. N. Lesch. 1982. A dairy cow body condition scoring system and its relationship to standard production characteristics. J. Dairy Sci. 65:495-501.

Wiles, P. G., I. K. Gray, and R. C. Kissling. 1998. Routine analysis of protein by Kjeldahl and Dumas methods: Review and interlaboratory study using dairy products. J. AOAC Int. 81:620-632.

Yamamoto, Y., Y. Deguchi, M. Mizutani, S. Urakawa, H. Yamada, H. Hiraoka, K. Inui, S. Kouno, and M. Goto. 2004. Improvement of fermentation quality and dry matter digestibility of rice wholecrop silage treated with fermented juice of epiphytic lactic acid bacteria and mechanical processing. Grassl. Sci. 49:665-668.

Yoshii, T., N. Asanuma, and T. Hino. 2005. Effect of ethanol on nitrate and nitrite reduction and methanogenesis in the ruminal microbiota. Anim. Sci. J. 76:37-42. 